\title{
Ligase do DNA
}

\section{Catarina Moreira}

Faculdade de Ciências da Universidade de Lisboa catarolina@gmail.com

\section{CITAÇÃO}

Moreira, C. (2014)

Ligase do DNA,

Rev. Ciência Elem., V2 (01):090.

doi.org/10.24927/rce2014.090

\section{EDITOR}

José Ferreira Gomes,

Universidade do Porto

\section{RECEBIDO EM}

16 de abril de 2011

\section{ACEITE EM}

13 de julho de 2011

\section{PUBLICADO EM}

05 de janeiro de 2012

\section{COPYRIGHT}

(C) Casa das Ciências 2019.

Este artigo é de acesso livre, distribuído sob licença Creative

Commons com a designação CC-BY-NC-SA 4.0, que permite a utilização e a partilha para fins não comerciais, desde que citado 0 autor e a fonte original do artigo.

rce.casadasciencias.org

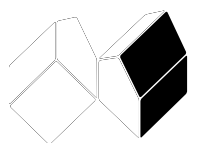

O processo completo decorre em 3 etapas:
1. adição de um resíduo de AMP (adenilação) ao centro ativo da enzima, e libertação de um pirofosfato
2. transferência de AMP para o grupo fosfato $5^{\prime}$ da chamada cadeia dadora, formação de uma ligação pirofosfato
3. formação de uma ligação fosfodiester entre o grupo fosfato 5' do dador e o grupo hidroxilo 3' do recetor

A ligase do DNA (ou DNA ligase) é uma enzima que promove a ligação entre os nucleótidos de duas moléculas de DNA.

Em Engenharia Genética e Genética Molecular esta enzima é extremamente importante, dado que esta enzima ajuda a reparar as descontinuidades das moléculas de DNA de cadeia dupla, unindo a cadeia. Por exemplo, as ligases do DNA são utilizadas em conjunto com as enzimas de restrição para inserir fragmentos de DNA em plasmídeos.

\section{Mecanismo de funcionamento da Ligase do DNA}

A ligase do DNA forma duas ligações fosfodiester covalentes entre a extremidade 3' hidroxilo de um nucleótido ("recetor") com a extremidade 5' fosfato de outro nucleótido ("dador"). Esta ação requer energia fornecida pelo ATP. 
As extremidades coesivas de dois fragmentos de DNA, obtidos por ação de enzimas de restrição, tendem a emparelhar devido à complementaridade das bases, e a ligação dos fragmentos é feita pela ação da ligase do DNA.

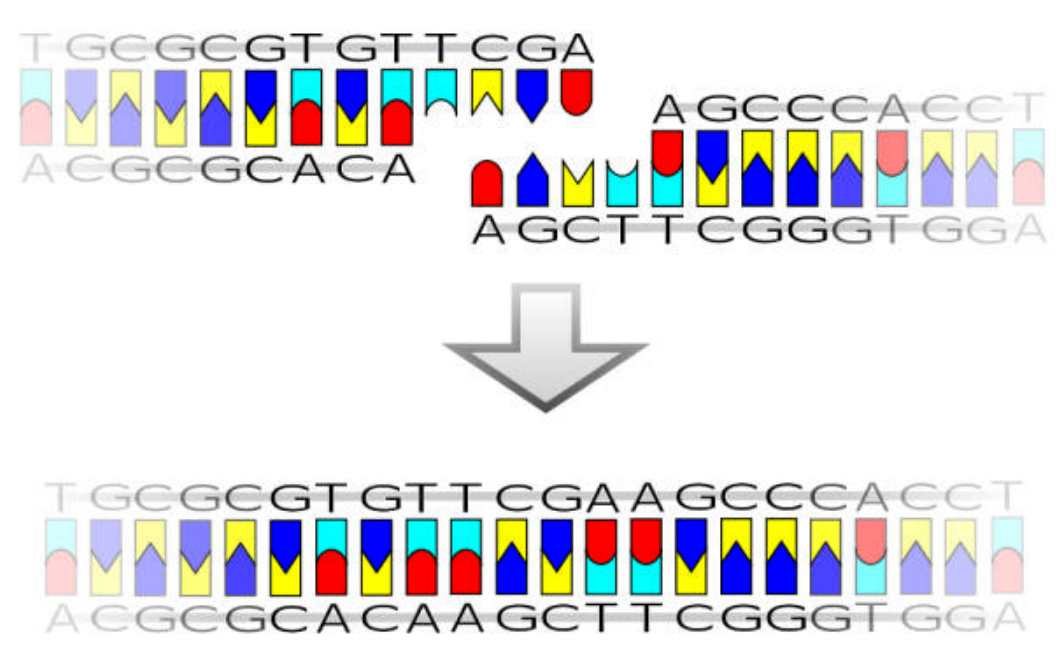

FIGURA 2. Esquema do emparelhamento entre duas extremidades coesivas sob a ação da ligase do DNA.

\section{REFERÊNCIAS}

${ }^{1}$ Wikipédia DNA ligase (http://en.wikipedia.org/wiki/DNA_ligase). 